\title{
Polychlorinated dibenzo-p-dioxins and dibenzofurans and polychlorinated biphenyls in surface soil from the Tibetan Plateau
}

\author{
Zhenyu Tian, Haifeng Li, Huiting Xie, Chen Tang, Ying Han, Mengjing Wang, Wenbin Liu* \\ State Key Laboratory of Environmental Chemistry and Ecotoxicology, Research Center for Eco-Environmental Sciences, Beijing 100085, China. \\ E-mail: tttonytian@gmail.com
}

\section{A R T I C L E I N F O}

Article history:

Received 15 November 2013

Revised 10 February 2014

Accepted 24 February 2014

Available online 21 August 2014

Keywords:

Cold-trap effect

Persistent organic pollutants

Indicator polychlorinated biphenyls

Inflection

Quadratic relation

\begin{abstract}
A B S T R A C T
Concentrations of Polychlorinated dibenzo-p-dioxins and dibenzofurans (PCDD/Fs) and polychlorinated biphenyls (PCBs) in soil samples from Tibetan Plateau were determined. The average concentration of total 2,3,7,8-PCDD/Fs was $(2.30 \pm 1.02) \mathrm{pg} / \mathrm{g}$, and World Health Organization Toxicity Equivalency (WHO-TEQ) average concentration was $(0.013 \pm 0.010)$ pg WHO-TEQ/g. The average concentration of $\sum$ PCBs (7 indicator PCB and 12 dioxin like-PCB congeners) was $(16.2 \pm 9.25) \mathrm{pg} / \mathrm{g}$, and WHO-TEQ average concentration was $0.043 \pm$ $0.049 \mathrm{pg}$ WHO-TEQ/g. Comparing to previous studies in similar environmental conditions, PCDD/Fs and PCBs in this study showed a relatively lower concentration. The altitude dependences of PCDD/Fs and PCBs were also studied. Total organic carbon (TOC) normalized concentrations presented a quadratic relation with the altitudes, and an inflection could be found on the parabola of the total concentrations and some congeners of high concentration. The concentrations decreased with altitudes below about $4500 \mathrm{~m}$ above sea level (a.s.l.), while they increased with altitudes above it. These phenomena indicate that cold condensation of PCDD/Fs and PCBs would happen above $4500 \mathrm{~m}$ a.s.l, on the Tibetan Plateau.

(C) 2014 The Research Center for Eco-Environmental Sciences, Chinese Academy of Sciences.
\end{abstract}

Published by Elsevier B.V.

\section{Introduction}

Polychlorinated dibenzo-p-dioxins and dibenzofurans (PCDD/Fs) and polychlorinated biphenyls (PCBs) are two groups of persistent organic pollutants (POPs) that are targeted for international source reduction by the Stockholm Convention. These chemicals are toxic and persistent, and they are able to accumulate in the tissues of organisms and undergo long-range atmospheric transport (LRAT). These properties have enabled them to become widely dispersed throughout the environment, even in some remote and relatively uncontaminated regions (Beyer et al., 2000; Wania and Westgate, 2008).

Cold and remote areas are considered to be sinks for POPs because of the long-range transport of POPs and the "grasshopper effect" (Simonich and Hites, 1995; Gouin et al., 2004). Low temperatures can enhance the deposition of POPs, acting as a "cold trap" for gas phase contaminants (Gong et al., 2010). Some POPs have been detected in different types of samples from high-latitude regions, including in the Arctic and the Antarctic (Bidleman et al., 2002; Weber and Goerke, 2003; Wang et al., 2012). It has also been reported that altitude has a strong effect on the distribution of POPs, and POPs have been studied on high plateaus and in mountainous regions (Ribes et al., 2002; Yang et al., 2010). Although it is controversial, correlations have been found between elevation and POP concentrations (Fernández and Grimalt, 2003; Borghini et al., 2005; Pan et al., 2013).

The Tibetan Plateau is bordered to the south by the Himalayan range. With an average altitude of more than $4500 \mathrm{~m}$ above sea level

\footnotetext{
* Corresponding author. E-mail: liuwb@rcees.ac.cn (Wenbin Liu).
} 
(m a.s.l.) and an area of about 2.5 million $\mathrm{km}^{2}$, the plateau is the highest and one of the largest in the world. The average annual temperature on the Tibetan Plateau is less than $10^{\circ} \mathrm{C}$, and in some parts it is around $0^{\circ} \mathrm{C}$ (Liu and Chen, 2000). The unique geographical characteristics and harsh meteorological conditions on the Tibetan Plateau mean that it is difficult to develop agriculture and industry, so the impact of human activities on the environment is limited, and atmospheric transport is considered to be the only source of POPs (Gong et al., 2010; Pan et al., 2013).

In this study, surface soil samples were collected from nine different sites at between 3500 and $5000 \mathrm{~m}$ a.s.l. on the Tibetan Plateau, and PCDD/Fs and PCBs present in the samples were quantified. The concentrations and congener profiles, and the potential factors that influenced them, were assessed, and relationships between the concentrations and altitude were analyzed. Acquiring these data and discussing the altitude dependence of the PCDD/F and PCB concentrations at such high elevations allows an assessment to be made of the behavior of these POPs in the pristine Tibetan Plateau environment.

\section{Experimental section}

\subsection{Soil sampling sites and methods}

The soil samples were collected during a scientific expedition in July 2012 in the southern part of the Tibetan Plateau, and the sampling sites were selected along the road between Lhasa and Shigatse. The positions of the sample sites are shown in Fig. 1, and they were between $28^{\circ} 52^{\prime} 47.11^{\prime \prime} \mathrm{N}$ and $30^{\circ} 34^{\prime} 12.88^{\prime \prime} \mathrm{N}$ and between $89^{\circ} 30^{\prime} 35.29^{\prime \prime} \mathrm{E}$ and $91^{\circ} 5^{\prime} 11.73^{\prime \prime} \mathrm{E}$, at altitudes of between 3594 and $5035 \mathrm{~m}$ a.s.l.

Sample no. 1 was collected near Namtso, which is the highest salt lake in the world. Samples no. 2 and no. 3 were collected near Yamdroktso, which is another high plateau lake. Samples no. 4 and no. 5 were collected by the side road S307, and samples no. 6 , no. 7 and no. 8 were collected from near road G318. Sample no. 9 was collected in Norbulingka of Lhasa. A number of surface soil samples (0-10 cm deep) were collected at each site using a stainless steel spade, and the samples were combined to form a mixed sample for the site. The samples were sealed in clean polyethylene bags, transported to the laboratory, and stored frozen (at $-20^{\circ} \mathrm{C}$ ) until analysis. The detailed information of the sampling sites, total organic carbon (TOC) of the samples, $\Sigma$ PCDD/Fs (total concentration of 2,3,7,8-PCDD/Fs), $\Sigma$ PCBs (total concentration of 12 dioxin like-PCBs and 7 indicator PCBs), World Health Organization Toxicity Equivalency (WHO-TEQ) of PCDD/Fs and PCBs in the samples were presented in Table 1.

\subsection{Sample analysis}

The soil samples were freeze-dried (for $24 \mathrm{hr}$ ), homogenized, and passed through a 60-mesh sieve. About $10 \mathrm{~g}$ of each sample was weighed and spiked with ${ }^{13} \mathrm{C}_{12}$-labeled PCDD/F (mixture 1613-LCS) and PCB (mixture 68A-LCS) standards (Wellington

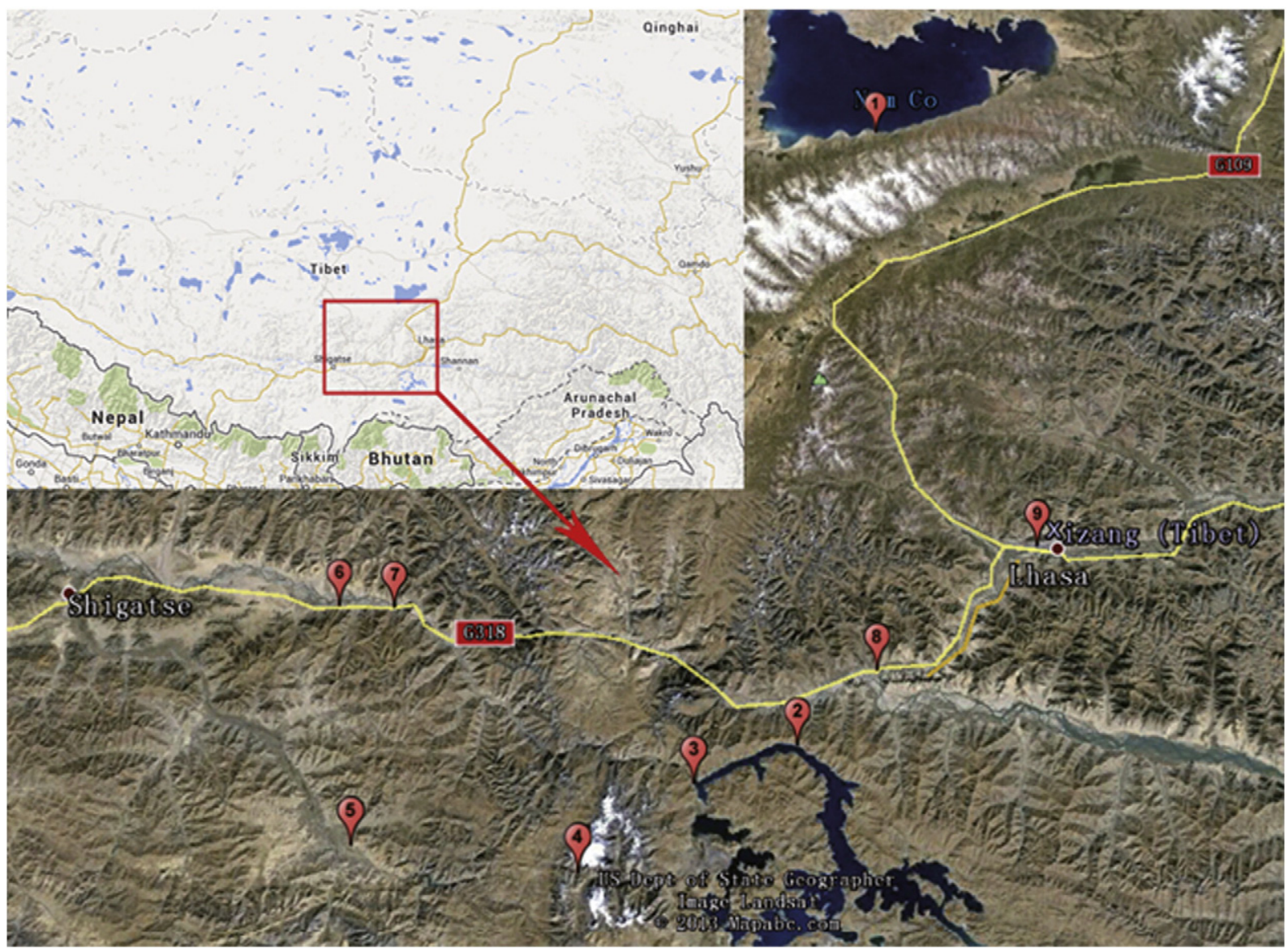

Fig. 1 - Surface soil sampling locations (no. 1-no. 9). 


\section{Table 1 - Detailed information on the sampling sites and total PCDD/F and PCB concentrations in the samples.}

\begin{tabular}{|c|c|c|c|c|c|c|c|c|}
\hline Site no. & Latitude & Longitude & $\begin{array}{l}\text { Altitude } \\
\text { (m a.s.l.) }\end{array}$ & $\begin{array}{c}\text { TOC } \\
(\mathrm{mg} \mathrm{C} / \mathrm{g})\end{array}$ & $\begin{array}{l}\Sigma \mathrm{PCDD} / \mathrm{Fs} \\
(\mathrm{pg} / \mathrm{g})\end{array}$ & $\begin{array}{l}\Sigma \mathrm{PCBs} \\
(\mathrm{pg} / \mathrm{g})\end{array}$ & $\begin{array}{c}\text { PCDD/Fs } \\
\text { (pg WHO-TEQ/g) }\end{array}$ & $\begin{array}{c}\text { PCBs } \\
\text { (pg WHO-TEQ/g) }\end{array}$ \\
\hline 1 & $30^{\circ} 34^{\prime} 12.88^{\prime \prime} \mathrm{N}$ & $90^{\circ} 35^{\prime} 41.41^{\prime \prime} \mathrm{E}$ & 4758 & 22.0 & 1.8 & 18.7 & 0.024 & 0.032 \\
\hline 2 & $29^{\circ} 11^{\prime} 17.03^{\prime \prime} \mathrm{N}$ & $90^{\circ} 35^{\prime} 50.00^{\prime \prime} \mathrm{E}$ & 4480 & 16.5 & 2.7 & 11.4 & 0.013 & 0.019 \\
\hline 3 & $29^{\circ} 5^{\prime} 14.50^{\prime \prime} \mathrm{N}$ & $90^{\circ} 22^{\prime} 57.67^{\prime \prime} \mathrm{E}$ & 4472 & 18.4 & 1.1 & 15.3 & 0.005 & 0.049 \\
\hline 4 & $28^{\circ} 53^{\prime} 41.29^{\prime \prime} \mathrm{N}$ & $90^{\circ} 9^{\prime} 54.56^{\prime \prime} \mathrm{E}$ & 5035 & 16.9 & 3.4 & 16.7 & 0.028 & 0.021 \\
\hline 5 & $28^{\circ} 52^{\prime} 47.11^{\prime \prime} \mathrm{N}$ & $89^{\circ} 39^{\prime} 54.93^{\prime \prime} \mathrm{E}$ & 4095 & 12.0 & 1.1 & 8.6 & 0.008 & 0.020 \\
\hline 6 & $29^{\circ} 19^{\prime} 56.90^{\prime \prime} \mathrm{N}$ & $89^{\circ} 30^{\prime} 35.29^{\prime \prime} \mathrm{E}$ & 3823 & 16.1 & 1.6 & 11.4 & 0.007 & 0.019 \\
\hline 7 & $29^{\circ} 20^{\prime} 43.21^{\prime \prime} \mathrm{N}$ & $89^{\circ} 38^{\prime} 11.42^{\prime \prime} \mathrm{E}$ & 3792 & 16.3 & 4.1 & 39.1 & 0.024 & 0.169 \\
\hline 8 & $29^{\circ} 21^{\prime} 29.00^{\prime \prime} \mathrm{N}$ & $90^{\circ} 45^{\prime} 16.97^{\prime \prime} \mathrm{E}$ & 3594 & 9.1 & 2.6 & 9.5 & 0.003 & 0.018 \\
\hline 9 & $29^{\circ} 39^{\prime} 7.80^{\prime \prime} \mathrm{N}$ & $91^{\circ} 5^{\prime} 36.92^{\prime \prime} \mathrm{E}$ & 3654 & 13.1 & 2.4 & 14.9 & 0.002 & 0.039 \\
\hline
\end{tabular}

Laboratories, Guelph, Canada), then extracted with a 1:1 (V/V) mixture of dichloromethane and $n$-hexane in an accelerated solvent extraction system (ASE 350; Dionex, USA). The extract was then sequentially cleaned using a multilayer silica gel column and a basic alumina column. The cleaned extract was concentrated to $20 \mu \mathrm{L}$ and spiked with a ${ }^{13} \mathrm{C}_{12}$-labeled injection standard. The extract was then analyzed using an Agilent 6890 high resolution gas chromatograph (HRGC; Agilent Technologies Inc., USA) connected to a Waters Autospec Ultima high resolution mass spectrometer (HRMS; Waters Corporation, USA). A DB-5 MS column (Agilent Technologies Inc., USA) was used to separate the target compounds. The temperature programs followed standard methods and are described in detail elsewhere (Liu et al., 2013a, 2013b). The HRMS was operated in selected ion monitoring mode at a resolution of $>10,000$. Field and laboratory blanks were incorporated into the analytical procedure for quality control. 2,3,7,8-substituted PCDD/Fs, 12 dioxin-like PCB (dl-PCB) congeners (PCB-77, 81, $105,114,118,123,126,156,157,167,169$, and 189), and 7 indicator PCB congeners (PCB-28, 52, 101, 118, 138, 153, and 180) were quantified. The recoveries of the PCDD/Fs were $38 \%-145 \%$ and the recoveries of the PCBs were $35 \%-186 \%$, satisfying the requirements of US EPA EPA-1613B and 1668A.

\section{Results and discussion}

\subsection{Concentrations and elevation gradient distribution}

The PCDD/F concentrations are shown in Fig. 2.

The PCDD/F concentrations in the soil samples were generally relatively low. The average total PCDD/F concentration was $2.30 \pm 1.02 \mathrm{pg} / \mathrm{g}(1.05-4.05 \mathrm{pg} / \mathrm{g})$, and WHO-TEQ average concentration was $0.013 \pm 0.010 \mathrm{pg} \mathrm{WHO}-\mathrm{TEQ} / \mathrm{g}(0.002-$ $0.028 \mathrm{pg}$ WHO-TEQ/g). The PCDD/F concentrations were lower than the concentrations found by Pan et al. (2013) in soil samples from a similar environment $(2.48-4.30 \mathrm{pg} / \mathrm{g})$. The PCDD/F concentrations in sample no. 7 were higher than the concentrations in the other samples, which could be explained by the fact that site 7 was located near a village. Thereby it may have been affected by the lives of residents.

1,2,3,7,8-PeCDF, 2,3,4,7,8-PeCDF, 2,3,7,8-TCDD, 1,2,3,7,8PeCDD, and 1,2,3,4,7,8-HxCDD were not detected in all of the soil samples. The most abundant congeners were OCDF and OCDD, which provided $6.6 \%-77.2 \%$ and $18.5 \%-70.4 \%$ of the total PCDD/F concentrations, respectively. 1,2,3,4,6,7,8-HpCDD and $1,2,3,4,6,7,8-\mathrm{HpCDF}$ were also important contributors to the total PCDD/F concentrations, providing $6.7 \%-17.1 \%$ and $4.3 \%-45.1 \%$ of the total PCDD/F concentrations, respectively. The PCDD/F homologue profiles are shown in Fig. 3, and it can be seen that the average contributions of the heptachlorinated and octa-chlorinated PCDD/F homologues were higher than those of the others.

It is clear that the more chlorinated PCDD/F congeners dominated the PCDD/F profiles. PCDD/Fs are seldom analyzed in high altitude soil samples, so there are few data with which to compare with our results. However, the congener patterns in our samples were similar to the patterns found in previous studies of atmospheric deposition (Ogura et al., 2001; Wang et al., 2006). There are little human activities in the region where the samples were collected, so the low concentrations and the congener profiles suggest that the PCDD/Fs found in the soil samples might have been deposited after long-range atmospheric transport.

It has been reported that elevation and TOC are important factors that affect the distribution of POPs (Daly and Wania, 2005). The average TOC of the soil samples was $15.6 \pm 3.8 \mathrm{mg} \mathrm{C} / \mathrm{g}$. For some congeners with relatively high concentrations, the relationships between altitude and their TOC normalized concentrationswere investigated (Fig. 4).

The TOC-normalized concentrations of typical PCDD/Fs congeners, total 2,3,7,8-PCDD/Fs congeners measured in this study have a quadratic relation with altitudes. A marked inflection was seen in the curves at an altitude of 4000-4500 $\mathrm{m}$ a.s.l. This will be discussed and explained later, in combination with a discussion of the altitude dependence of the PCB concentrations.

\subsection{Concentrations and elevation gradient distribution of PCBs}

The PCB concentrations in the soil samples are shown in Table 2.

The average concentration of the sum of the 18 PCB congeners that were analyzed was $16.2 \pm 9.25 \mathrm{pg} / \mathrm{g}(8.53-39.1 \mathrm{pg} / \mathrm{g})$, and the average WHO-TEQ concentration was $0.043 \pm 0.049 \mathrm{pg}$ WHO$\mathrm{TEQ} / \mathrm{g}$ (0.018-0.17 pg WHO-TEQ/g). The concentrations were similar to or lower than concentrations found in previous studies on high plateaus and in mountainous areas (Wang et al., 2009; 


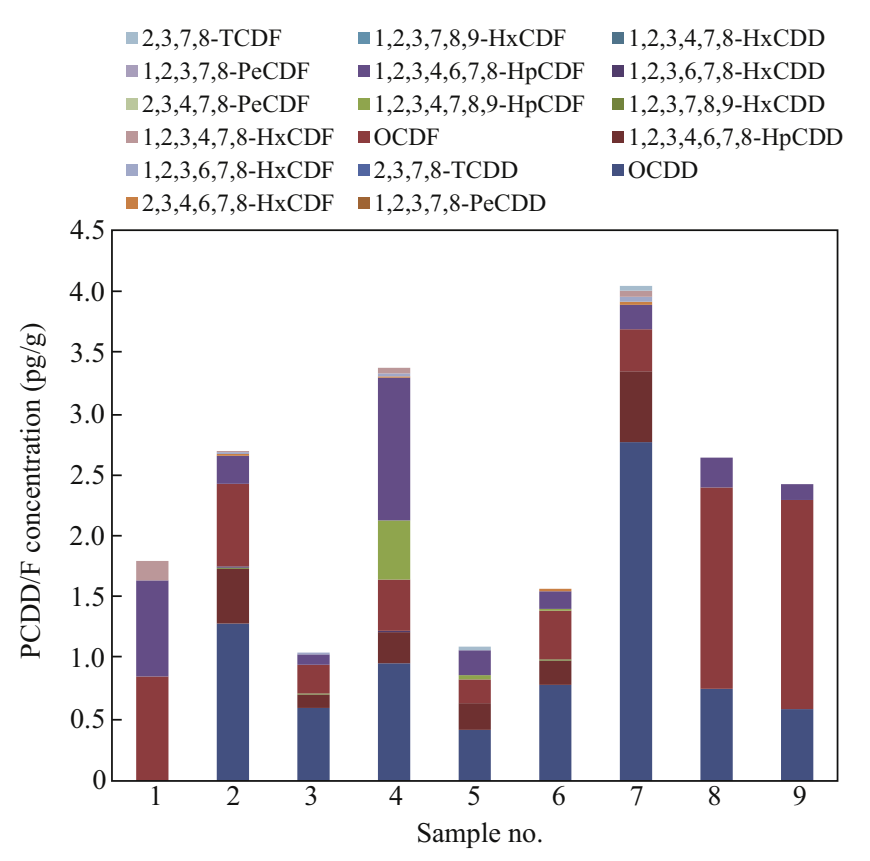

Fig. 2 - Concentrations of the 2,3,7,8-PCDD/Fs in the soil samples.

Pan et al., 2013). All the 18 PCB congeners were detected, and the most abundant indicator PCB congeners were PCB-28 and PCB-52, which provided $30.7 \%-61.6 \%$ and $7.6 \%-17.0 \%$ of the total $\mathrm{PCB}$ concentrations, respectively. The dl-PCBs PCB-77, PCB-105 and PCB-118 provided $0 \%-8.6 \%, 1.3 \%-3.1 \%$, and $3.3 \%-7.6 \%$ of the total PCB concentrations, respectively. The congener profiles were close to those found in similar environments (Blais et al., 1998; Weiss et al., 2000; Estellano et al., 2008).

As for the elevation gradient distribution, PCBs showed a similar tendency with PCDD/Fs in some relatively high levels of congeners, such as PCB-28, PCB-52, PCB-101 and total PCBs (Fig. 5).

TOC-normalized concentrations of some PCB congeners also showed an inflection in the range of $4000-4500 \mathrm{~m}$ a.s.l. from quadratic relation with altitudes (Fig. 5). However, for PCB congeners with lower concentrations, the relationships between the TOC-normalized concentrations of PCB congeners and the altitude were complex. As some of these congeners were scarce in quantity, their elevation dependence might be affected by the universal background level the soil, limit of detection, and other uncertain factors.

Previous studies of POPs on the Tibetan Plateau have shown positive dependences of POP concentrations on altitude all the way from the plateau to the high mountains (Chen et al., 2008; Pan et al., 2013), and this was interpreted as a sign of the cold condensation effect. Chen et al. (2008) found that PCB and organochlorine pesticide concentrations had positive dependences on altitudes (between 2636 and $4479 \mathrm{~m}$ a.s.l.) in Sichuan and on the Tibetan Plateau (Chen et al., 2008). Pan et al. (2013) found a similar positive correlation

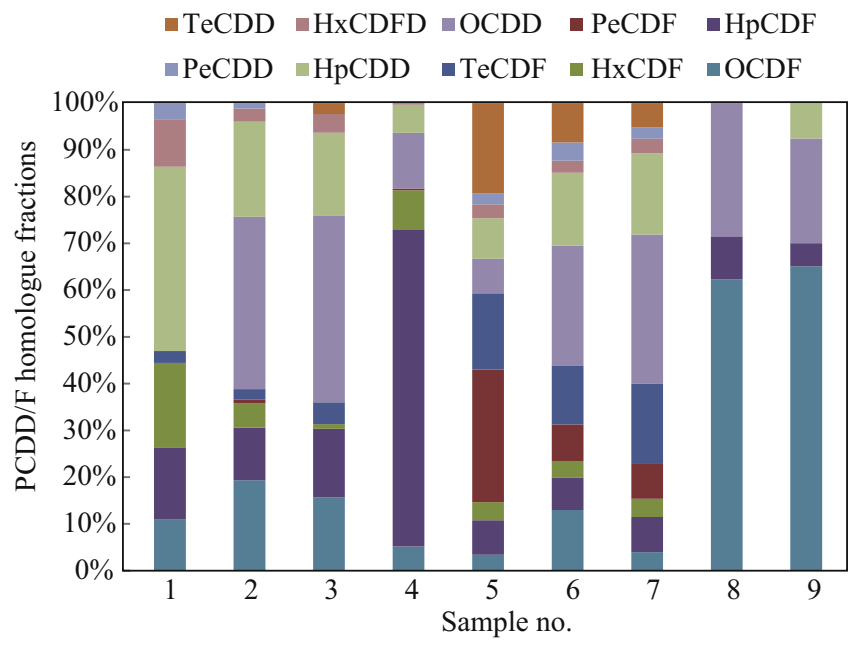

Fig. 3 - PCDD/F homologue fractions in the soil samples. 

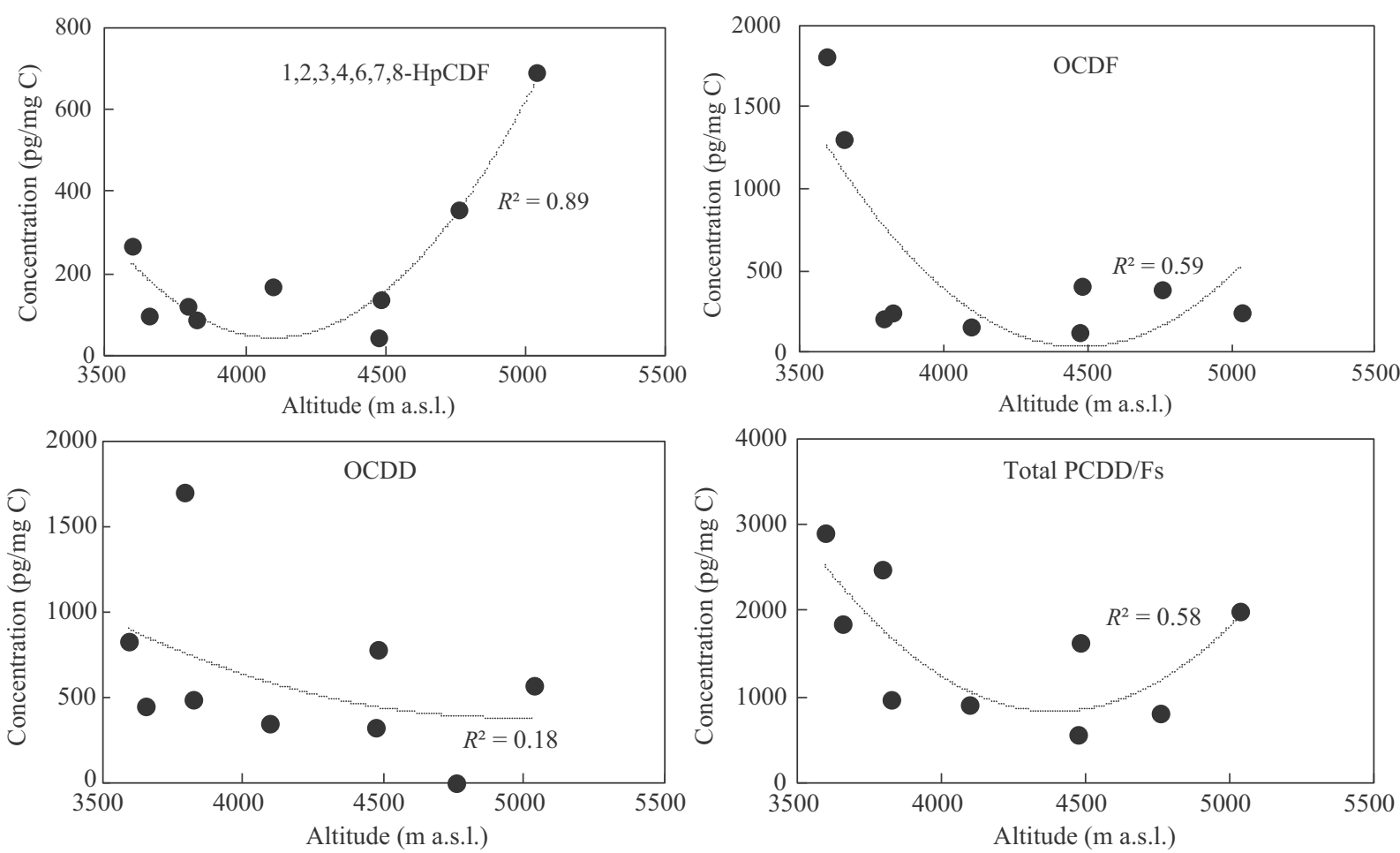

Fig. 4 - Relationships between altitude and TOC-normalized concentrations of high-leveled PCDD/F congeners and total 2,3,7,8-PCDD/Fs.

between PCB and PCDD/F concentrations and altitude at similar elevations (2806-4487 $\mathrm{m}$ a.s.l.). However, other studies have shown contradictory or complex relationships between POP concentrations and altitude. Liu et al. (2010) found that $\mathrm{HCH}$ concentrations in air samples from Tibet (taken at 1242-4485 $\mathrm{m}$ a.s.l.) positively correlated with altitude, but

\begin{tabular}{|c|c|c|c|c|c|c|c|c|c|}
\hline Sample & 1 & 2 & 3 & 4 & 5 & 6 & 7 & 8 & 9 \\
\hline PCB-77 & 0.26 & 0.64 & 0.24 & ND & 0.33 & 0.11 & 3.37 & 0.16 & 0.39 \\
\hline PCB-81 & 0.08 & ND & 0.04 & ND & ND & 0.03 & 0.05 & ND & ND \\
\hline PCB-105 & 0.30 & 0.17 & 0.47 & 0.21 & 0.18 & 0.17 & 1.64 & 0.16 & 0.36 \\
\hline PCB-114 & 0.06 & 0.06 & 0.07 & ND & 0.05 & 0.06 & 0.16 & 0.07 & 0.07 \\
\hline PCB-118 & 0.74 & 0.60 & 1.05 & 0.54 & 0.33 & 0.34 & 2.99 & 0.32 & 0.75 \\
\hline PCB-123 & 0.11 & 0.32 & 0.09 & ND & 0.05 & 0.10 & 0.32 & 0.04 & 0.09 \\
\hline PCB-126 & 0.13 & 0.06 & ND & ND & 0.03 & 0.07 & 0.10 & ND & 0.03 \\
\hline PCB-156 & 0.12 & 0.31 & 0.34 & ND & 0.19 & 0.37 & 0.33 & ND & 0.14 \\
\hline PCB-157 & 0.06 & 0.15 & 0.17 & 0.12 & ND & 0.24 & 0.11 & ND & 0.11 \\
\hline PCB-167 & 0.04 & 0.09 & 0.10 & ND & ND & 0.18 & 0.23 & 0.20 & 0.08 \\
\hline PCB-169 & 0.08 & 0.09 & ND & ND & 0.06 & 0.15 & 0.10 & 0.19 & 0.07 \\
\hline PCB-189 & 0.09 & ND & 0.06 & ND & 0.06 & ND & ND & ND & 0.29 \\
\hline PCB-28 & 11.03 & 4.93 & 4.71 & 10.29 & 4.48 & 6.23 & 14.02 & 5.21 & 6.82 \\
\hline PCB-52 & 1.82 & 1.53 & 1.17 & 2.49 & 1.18 & 1.16 & 6.67 & 1.11 & 2.09 \\
\hline PCB-101 & 1.10 & 0.61 & 0.90 & 1.63 & 0.57 & 0.53 & 2.77 & 0.50 & 0.89 \\
\hline PCB-138 & 1.25 & 0.75 & 3.14 & 0.59 & 0.57 & 0.85 & 3.68 & 0.76 & 1.45 \\
\hline PCB-153 & 0.94 & 0.76 & 1.87 & 0.82 & 0.32 & 0.60 & 2.50 & 0.51 & 0.88 \\
\hline PCB-180 & 0.48 & 0.35 & 0.91 & 0.00 & 0.13 & 0.18 & 0.06 & 0.20 & 0.35 \\
\hline$\sum \mathrm{PCBS}$ & 18.7 & 11.4 & 15.3 & 16.7 & 8.53 & 11.4 & 39.1 & 9.43 & 14.9 \\
\hline
\end{tabular}

DDT and its derivatives had the opposite relationship (Liu et al., 2010). Based on PCB and PBDE concentrations in soil samples from a wider altitude range (3689-6378 $\mathrm{m}$ a.s.l.), Wang et al. (2009) proposed a complex correlation model, finding that the concentrations negatively depended on the altitude in the lower plateau region, below $4500 \mathrm{~m}$ a.s.l., but that the concentrations positively depended on the altitude to a significant degree in the mountainous region, above $4500 \mathrm{~m}$ a.s.l.

In our study (3594-5035 $\mathrm{m}$ a.s.l.), the dependence of the PCB and PCDD/F concentrations on altitude agreed with the findings of Wang et al. (2009), described above. Although cold condensation dominated at high elevations in the mountains, this was not clearly the case in the mid-high plateau region. The average annual temperatures in the high altitude areas where samples no. 1 and no. 4 were collected are 1.7 and $2.6^{\circ} \mathrm{C}$, respectively, whereas the average annual temperatures in the lower areas where samples no. 8 and no. 9 were collected are 6.6 and $7.5^{\circ} \mathrm{C}$, respectively (Yang et al., 2006). The sampling sites used by Wang et al. (2009) that were above $5000 \mathrm{~m}$ a.s.l. have average temperatures of below $0^{\circ} \mathrm{C}$. It is, therefore, possible that the mountain cold-trap effect only occurs under a restricted range of conditions.

\section{Conclusions}

PCDD/F and PCB concentrations in surface soil samples from the Tibetan Plateau were relatively low. The PCDD/F congener profiles were dominated by the hepta- and octa-chlorinated congeners, the PCB congener profiles 

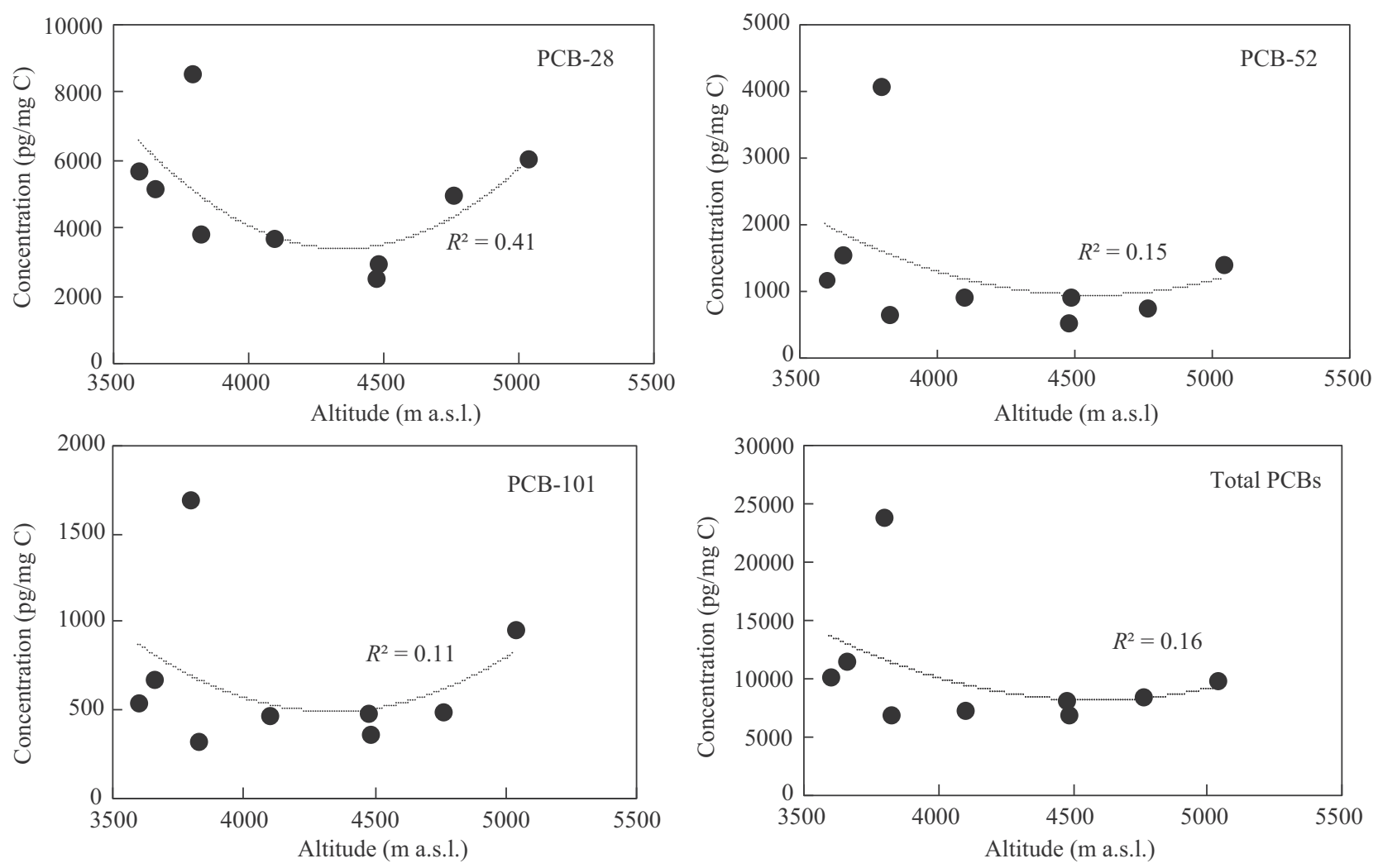

Fig. 5 - Relationships between altitude and the TOC-normalized concentrations of some PCB congeners and the total PCB concentrations.

were dominated by PCB-28 and PCB-52. These congener profiles were similar to those found in previous studies in similar environments. Long-range atmospheric transport seems to be the source of these POPs to the Tibetan Plateau. The PCDD/F and PCB concentrations depended on the altitude in a complex way, and an inflection was seen in the concentration-altitude curves for high-leveled PCDD/F and PCB congener and for the total PCDD/Fs and PCBs. These phenomena indicate that cold condensation of PCDD/Fs and PCBs would happen above $4500 \mathrm{~m}$ a.s.l, on the Tibetan Plateau.

\section{Acknowledgments}

This work was supported by the National Basic Research Program (973) of China (No. 2011CB201500), the Environmental Public Welfare Projects (No. 201209019), the National High Technology Research and Development Program (863) of China (No. 2012AA062803) and the National Natural Science Foundation of China (No. 21477150, 21321004).

\section{R E F E R E N C E S}

Beyer, A., Mackay, D., Matthies, M., Wania, F., Webster, E., 2000. Assessing long-range transport potential of persistent organic pollutants. Environ. Sci. Technol. 34 (4), 699-703.
Bidleman, T.F., Jantunen, L.M., Helm, P.A., Brorström-Lundén, E., Juntto, S., 2002. Chlordane enantiomers and temporal trends of chlordane isomers in arctic air. Environ. Sci. Technol. 36 (4), 539-544.

Blais, J.M., Schindler, D.W., Muir, D.C., Kimpe, L.E., Donald, D.B., Rosenberg, B., 1998. Accumulation of persistent organochlorine compounds in mountains of western Canada. Nature 395 (6702), 585-588.

Borghini, F., Grimalt, J.O., Sanchez-Hernandez, J.C., Barra, R., García, C.J.T., Focardi, S., 2005. Organochlorine compounds in soils and sediments of the mountain Andean Lakes. Environ. Pollut. 136 (2), 253-266.

Chen, D., Liu, W., Liu, X., Westgate, J.N., Wania, F., 2008. Cold-trapping of persistent organic pollutants in the mountain soils of Western Sichuan, China. Environ. Sci. Technol. 42 (24), 9086-9091.

Daly, G.L., Wania, F., 2005. Organic contaminants in mountains. Environ. Sci. Technol. 39 (2), 385-398.

Estellano, V.H., Pozo, K., Harner, T., Franken, M., Zaballa, M., 2008. Altitudinal and seasonal variations of persistent organic pollutants in the Bolivian Andes mountains. Environ. Sci. Technol. 42 (7), 2528-2534.

Fernández, P., Grimalt, J.O., 2003. On the global distribution of persistent organic pollutants. CHIMIA Int. J. Chem. 57 (9), 514-521.

Gong, P., Wang, X., Sheng, J., Yao, T., 2010. Variations of organochlorine pesticides and polychlorinated biphenyls in atmosphere of the Tibetan Plateau: role of the monsoon system. Atmos. Environ. 44 (21-22), 2518-2523.

Gouin, T., Mackay, D., Jones, K.C., Harner, T., Meijer, S.N., 2004. Evidence for the "grasshopper" effect and fractionation during long-range atmospheric transport of organic contaminants. Environ. Pollut. 128 (1), 139-148. 
Liu, X., Chen, B., 2000. Climatic warming in the Tibetan Plateau during recent decades. Int. J. Climatol. 20 (14), 1729-1742.

Liu, W., Chen, D., Liu, X., Zheng, X., Yang, W., Westgate, J.N., Wania, F., 2010. Transport of semivolatile organic compounds to the Tibetan Plateau: spatial and temporal variation in air concentrations in mountainous Western Sichuan, China. Environ. Sci. Technol. 44 (5), 1559-1565.

Liu, W., Li, H., Tian, Z., Xie, H., Hu, J., 2013a. Spatial distribution of polychlorinated biphenyls in soil around a municipal solid waste incinerator. J. Environ. Sci. 25 (8), 1636-1642.

Liu, W., Li, H., Tian, Z., Xie, H., Li, C., 2013b. Spatial distribution of polychlorinated dibenzo-p-dioxins and polychlorinated dibenzofurans in soil around a municipal solid waste incinerator. Environ. Geochem. Health 35 (5), 605-611.

Ogura, I., Masunaga, S., Nakanishi, J., 2001. Congener-specific characterization of PCDDs/PCDFs in atmospheric deposition: comparison of profiles among deposition, source, and environmental sink. Chemosphere 45 (2), 173-183.

Pan, J., Yang, Y., Zhu, X., Yeung, L.W., Taniyasu, S., Miyake, Y., et al., 2013. Altitudinal distributions of PCDD/Fs, dioxin-like PCBs and PCNs in soil and yak samples from Wolong high mountain area, eastern Tibet-Qinghai Plateau, China. Sci. Total Environ. 444, 102-109.

Ribes, A., Grimalt, J.O., Torres García, C.J., Cuevas, E., 2002. Temperature and organic matter dependence of the distribution of organochlorine compounds in mountain soils from the subtropical Atlantic (Teide, Tenerife Island). Environ. Sci. Technol. 36 (9), 1879-1885.

Simonich, S.L., Hites, R.A., 1995. Global distribution of persistent organochlorine compounds. Science 269 (5232), 1851-1854.
Wang, X., Yao, T., Cong, Z., Yan, X., Kang, S., Zhang, Y., 2006. Gradient distribution of persistent organic contaminants along northern slope of central-Himalayas, China. Sci. Total Environ. 372 (1), 193-202.

Wang, P., Zhang, Q., Wang, Y., Wang, T., Li, X., Li, Y., Ding, L., Jiang, G., 2009. Altitude dependence of polychlorinated biphenyls (PCBs) and polybrominated diphenyl ethers (PBDEs) in surface soil from Tibetan Plateau, China. Chemosphere 76 (11), 1498-1504.

Wang, P., Zhang, Q., Wang, T., Chen, W., Ren, D., Li, Y., Jiang, G., 2012. PCBs and PBDEs in environmental samples from King George Island and Ardley Island, Antarctica. RSC Adv. 2 (4), 1350.

Wania, F., Westgate, J.N., 2008. On the mechanism of mountain cold-trapping of organic chemicals. Environ. Sci. Technol. 42 (24), 9092-9098.

Weber, K., Goerke, H., 2003. Persistent organic pollutants (POPs) in antarctic fish: levels, patterns, changes. Chemosphere 53 (6), 667-678.

Weiss, P., Lorbeer, G., Scharf, S., 2000. Regional aspects and statistical characterisation of the load with semivolatile organic compounds at remote Austrian forest sites. Chemosphere 40 (9), 1159-1171.

Yang, X., Zhang, Y., Zhang, W., Yan, Y., Wang, Z., Ding, M., Chu, D., 2006. Climate change in Mt. Qomolangma region in China during the last 34 years. Acta Geograph. Sin. 61 (7), 687-696.

Yang, R., Wang, Y., Li, A., Zhang, Q., Jing, C., Wang, T., Wang, P., Li, Y., Jiang, G., 2010. Organochlorine pesticides and PCBs in fish from lakes of the Tibetan Plateau and the implications. Environ. Pollut. 158 (6), 2310-2316. 